\title{
A CHLORITE CONTAINER FOUND ON THE SURFACE OF SHAHDAD (KERMAN, IRAN) AND ITS COSMETIC CONTENT
}

\author{
By Massimo Vidale, ${ }^{*}$ Oliver Craig, ${ }^{* *}$ François Desset, ${ }^{* * *}$ Giuseppe Guida, ${ }^{*}$ Pierluigi \\ Bianchetti, ${ }^{*}$ Giancarlo Sidoti, ${ }^{*}$ Maurizio Mariottini, ${ }^{*}$ Enrico Battistella**** \\ *Istituto Superiore per la Conservazione e il Restauro, Rome, ${ }^{* *}$ University of York, \\ ${ }^{* * *}$ Université de Paris I Panthéon-Sorbonne, ${ }^{* * * *}$ University of Bologna, Italy
}

\begin{abstract}
Analysis of a stone flagon found on the surface of the early urban site of Shahdad (Kerman, Iran) has shown that the vessel contained a lead-based cosmetic. Other finds recovered from the same surface context suggest a dating within the second half of the fourth millennium BC or slightly later. X-Ray Diffraction (XRD), Scanning Electron Microscopy equipped with an Energy Dispersive Spectrometer, Thermogravimetric Analysis (TGA), Fourier Transform Infrared Spectroscopy (FTIR) and Gas Chromatography with Mass Spectrometry (GC-MS) have been used to reconstruct the manufacturing techniques of the cosmetic. The substance was likely made of artificial lead carbonates. As our find and recent studies confirm that wet chemical processing of lead was common in the third millennium BC, the social implications of cosmetology in the early cities of the Near East and Middle Asia of the fourth-third millennia BC are briefly addressed.
\end{abstract}

Keywords

Shahdad; lead white; ancient cosmetics

\section{INTRODUCTION: THE FIND AND ITS CONTEXT}

The archaeological site of Shahdad (ancient Khabis) is located in the north-western edge of the Lut desert $\left(30^{\circ} 26^{\prime} 07,78^{\prime \prime} \mathrm{N}, 57^{\circ} 45^{\prime} 12,01^{\prime \prime} \mathrm{E}, c .430 \mathrm{~m}\right.$ asl), about $65 \mathrm{~km}$ east of Kerman, eastern Iran (Fig. 1). Growing between the peaks of Dahaneh-ye Ghar, Kuh-e Joftan and Sirch (c. $4000 \mathrm{~m}$ asl) and the Takab plains, at the edges of the endoreic fan of the river Derakhtangan, Shahdad was settled since at least the late fifth millennium $\mathrm{BC}$ up to the present. ${ }^{1}$ Besides the abundant surface and underground water, ${ }^{2}$ the town was a caravan routes' crossroads, being located near important mineral resources. The specialisation of its craft communities in the production of copper and semiprecious stones explains part of the wealth of its Bronze Age graves (second half of the third to the beginning of the second millennium BC). Surface surveys show that the ancient town developed shifting westward, from a late fifth millennium BC tepe

Hakemi 1997; Kaboli 1997; Salvatori and Vidale 1982. Gentelle 2003. and a mid-fourth millennium $\mathrm{BC}$ tepe to the east, up to a city of $80-100$ ha in the second half of the third millennium BC (Fig. 2). ${ }^{3}$ However, this important site complex is still largely unexplored.

The traditional agricultural products of the farmers of Shahdad are palm dates and fruits, and centuries ago Shahdad was famous for its silk production. ${ }^{4}$ The environment of Shahdad is desertic (Dasht-e Lut), and the climate continental, i.e. hot and arid in summer, very cold and windy in winter. The landscape is spotted by desert shrub vegetation on thick alluvial layers dissected by the wind into yardangs, ${ }^{5}$ with buried soils truncated by erosion and topped by crusts of evaporitic salts and carbonates. Yardangs cover the third millennium BC settlement, but not the emerging fourth millennium BC mounded area (Tepes I and II, towards the eastern limits of the site, see Fig. 2).

A chlorite 6 flagon was found on the surface of

3 Salvatori and Vidale 1982; Hakemi 1997; Kaboli 1997; and recent visits to the site by the authors.

4 Gentelle 2003.

5 Meder 1979; Hakemi 1997: 25-37.

6 Visual identification by MV, based upon his familiarity with this type of rocks, and analytically confirmed by the traces 


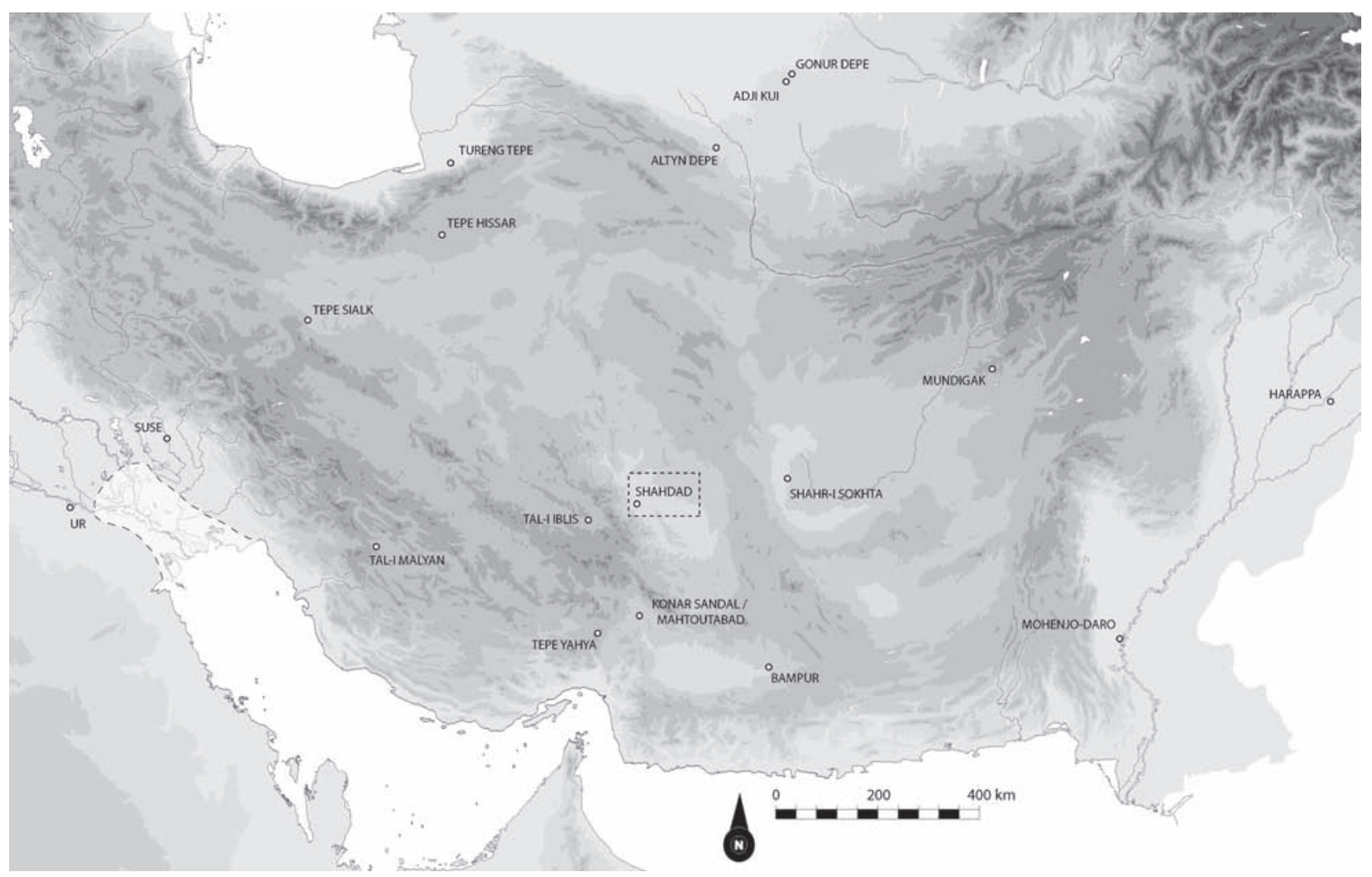

Fig. 1. The location of Shahdad and of other important protohistoric sites of Middle Asia (F. Desset).

Tepe I (Fig. 2 and Fig. 3), in January 2009, together with black-on-buff painted wall fragments with oblique bands and simple cross-hatched lozenge patterns (Fig. 4), and many fragments of Aliabad conical ring-footed vases identical to those found in Mahtoutabad II-Iblis IV contexts in south-eastern Iran (Figs. 5 and 6). This pottery is datable c. $3600-3300$ BC. ${ }^{7} \mathrm{~A}$ large necked jar with a horizontal impressed ridge (Fig. 7) and sherds with pierced ear and nose-like lugs (Fig. 8) recall other late fourth millennium BC assemblages of the central-western Iranian Plateau. After careful scrutiny, no third millennium BC material was found on the surface of Tepe I. The chronological span of this context (with all the caution required by a surface find) may be hypothetically ascribed to $c$. 3600-2900 BC.

The flagon, made of a dark green-grey chlorite, is a cylinder, $15.5 \mathrm{~cm}$ long and $3.6 \mathrm{~cm}$ wide at the

of clinochlore detected in the X-ray patterns of the content: see below, Fig. 12b, layers 2-4).

7 Vidale and Desset in press; see Madjidzadeh and Pittman 2008; Caldwell 1967. maximum expansion (Fig. 9). The mouth is slightly restricted (outer diameter on the lip 3.35-3.4 cm; inner mouth diameter c. $2 \mathrm{~cm}$ ). The lip slightly protrudes outwards, and the base is flat. The wall below the rim is about $0.55-0.60 \mathrm{~cm}$ thick. So far it has no known comparanda. ${ }^{8}$ Recorded and sampled, the flagon was handed over to the archaeological representatives of ICHTO, Kerman.

Preliminary chemical analysis by SEM (see details below) revealed that the substance sampled inside the flagon was a cosmetic mainly made of lead carbonates (cerussite and hydrocerussite). In the following section we present and discuss the inner stratigraphy of the substance contained in the stone receptacle, as revealed by a careful micro-excavation.

8 As confirmed by S. Salvatori (pers comm). The only exception could be a vaguely similar "cylindrical tall jar", 10.2 $\mathrm{cm}$ tall, $4.6 \mathrm{~cm}$ at the mouth, published in Madjidzadeh 2003: 121, but without context and dating. 


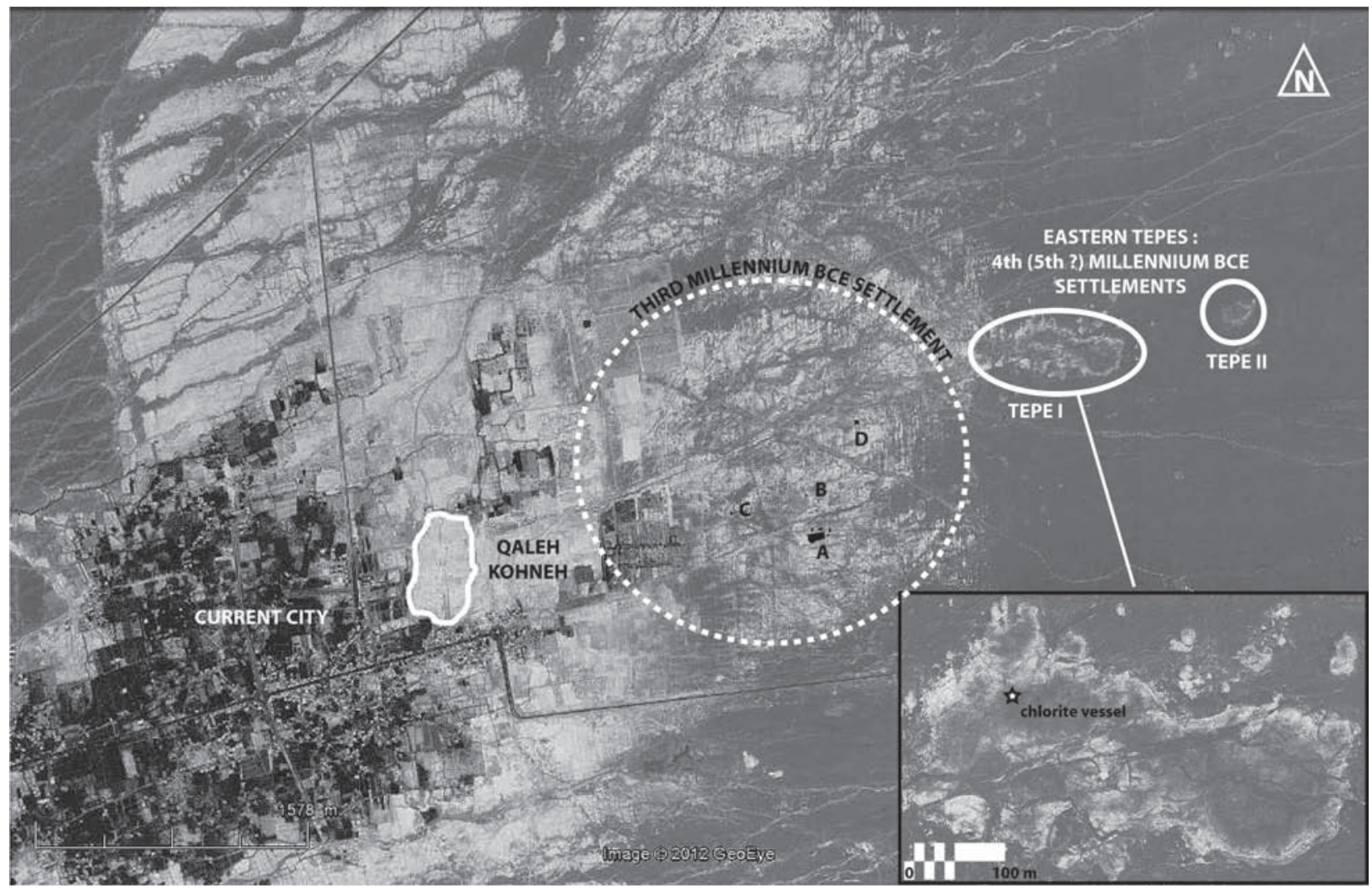

Fig. 2. Google Earth picture of the area of Shahdad and archaeological interpretation showing the location of Qaleh Kohneh, of the third millennium BCE settlement and the trenches opened by Ali Hakemi (trenches A, B, C and D) and of the eastern tepes I (fourth millennium BCE) and II (fifth-fourth millennium BCE). The star marks the area where the late fourth millennium BCE ceramics were observed and the chlorite container found on surface (F. Desset).

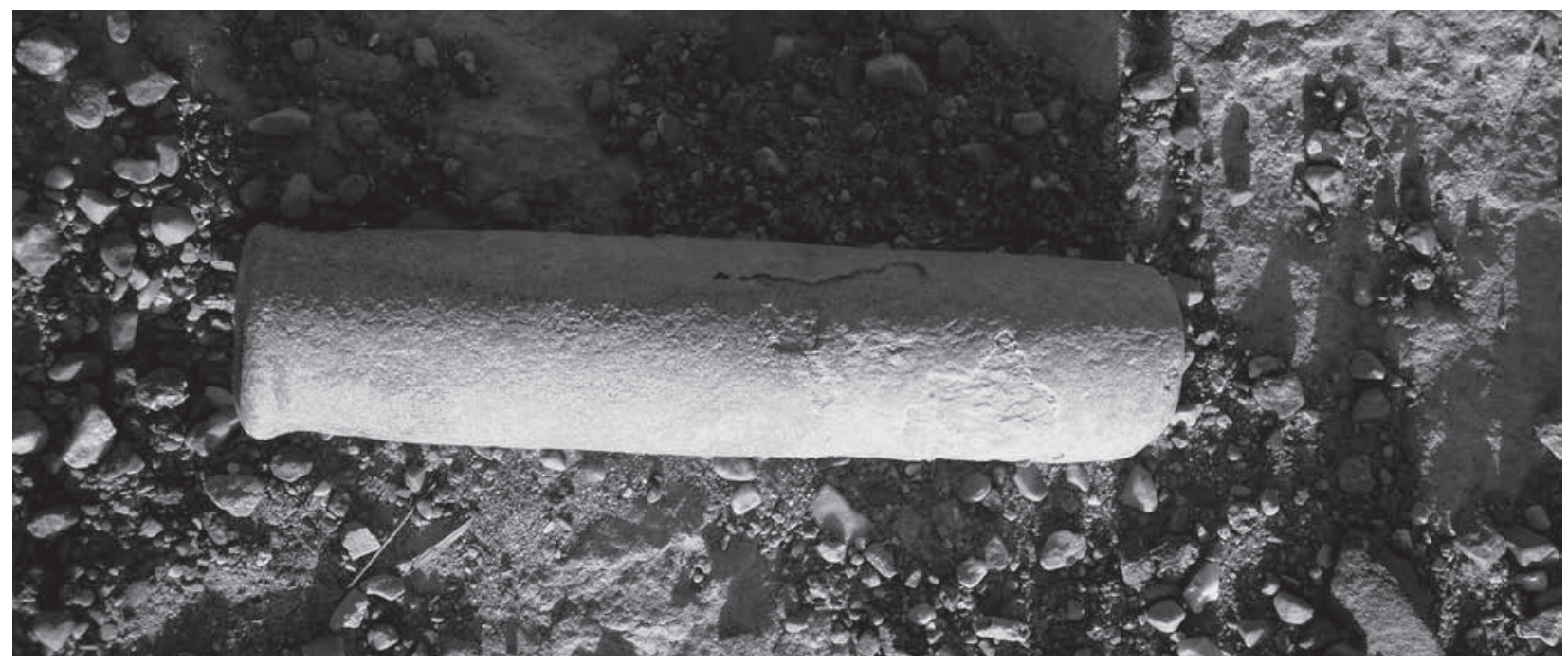

Fig. 3. Shahdad 2009, the chlorite flagon as found on surface. 


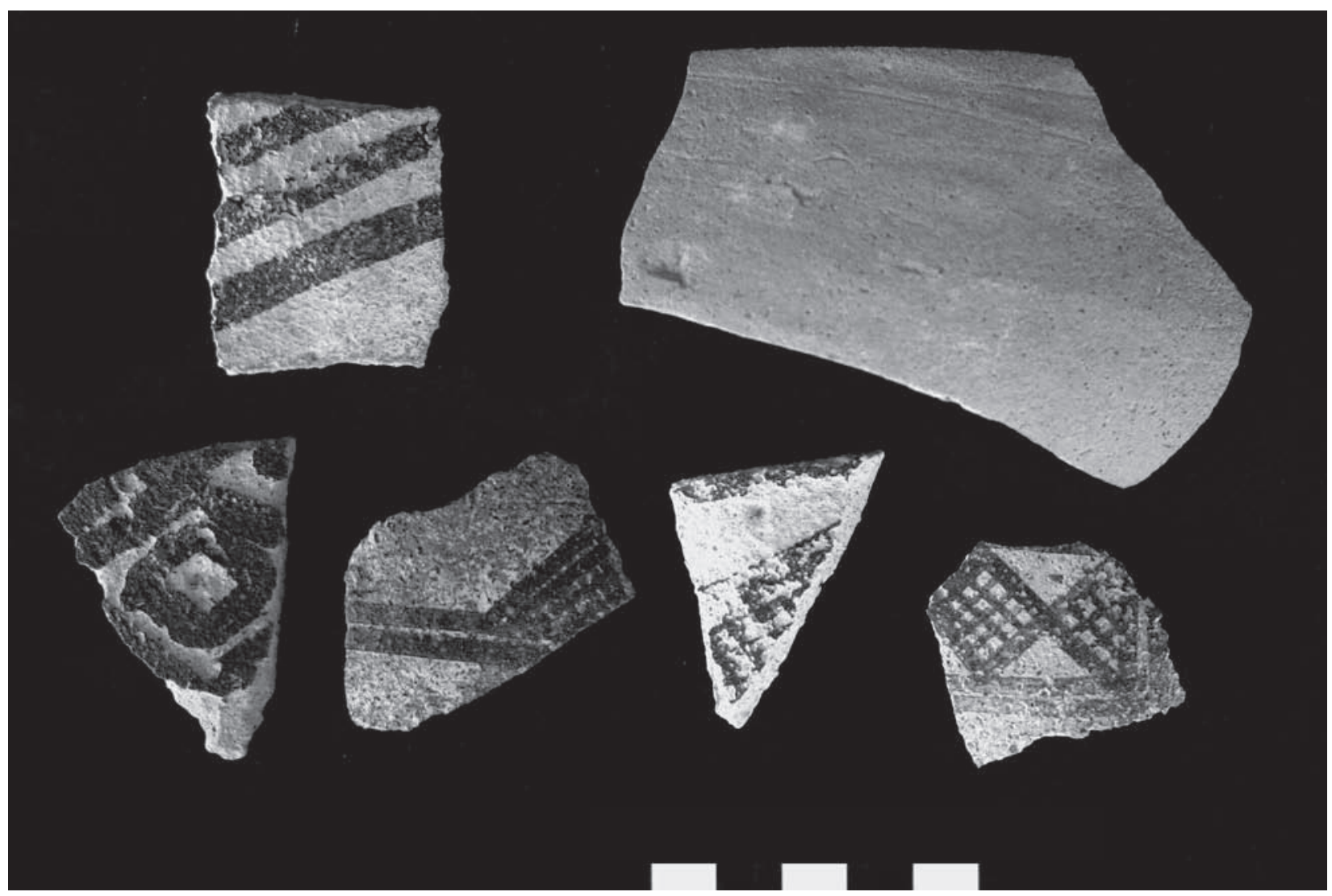

Fig. 4. Shahdad 2009, black-on-buff painted wall fragments with oblique bands and simple cross-hatched lozenge patterns (below) and overfired unpainted bowl (upper right).

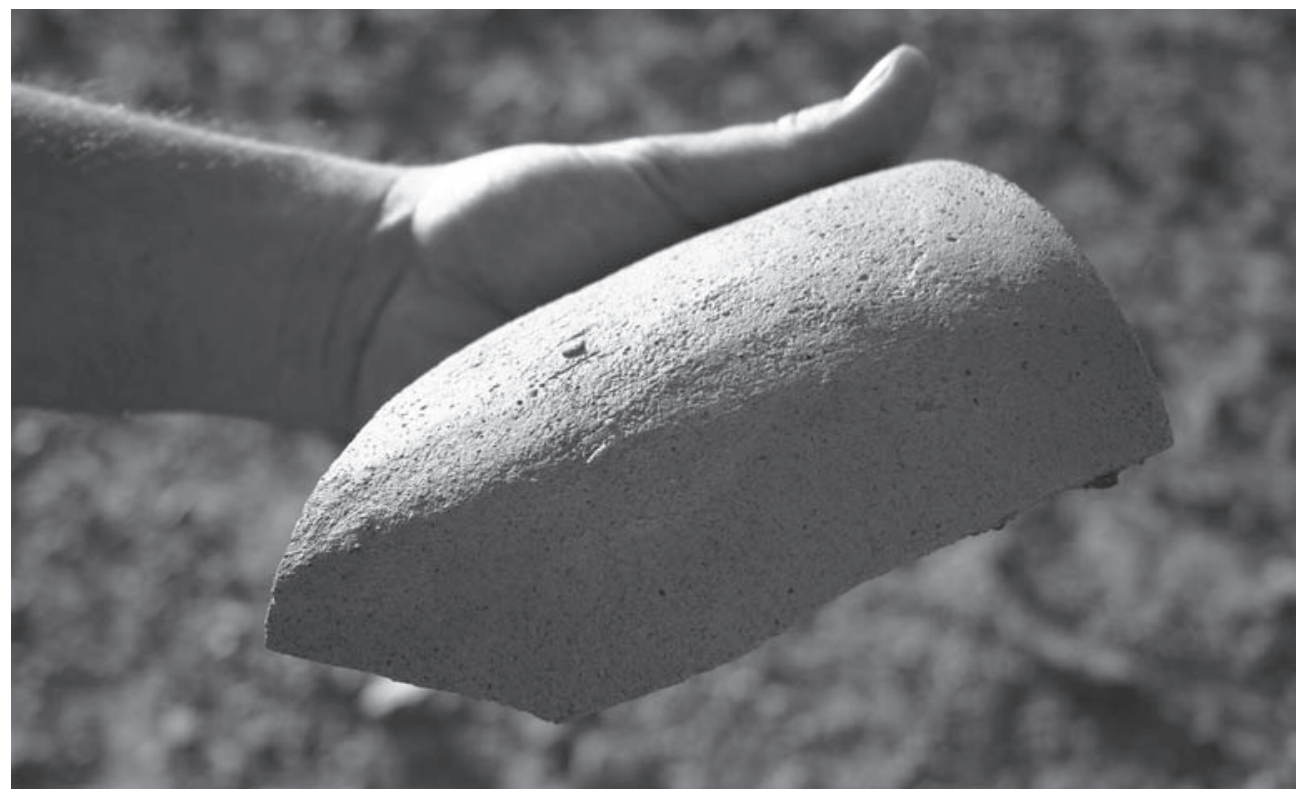

Fig. 5. Shahdad 2009, fragment of a conical footed Aliabad-Iblis IV vessel comparable to those found below the level of the third millennium graveyard at Mahtoutabad (Konar Sandal), dating to the middle of the fourth millennium BCE. 


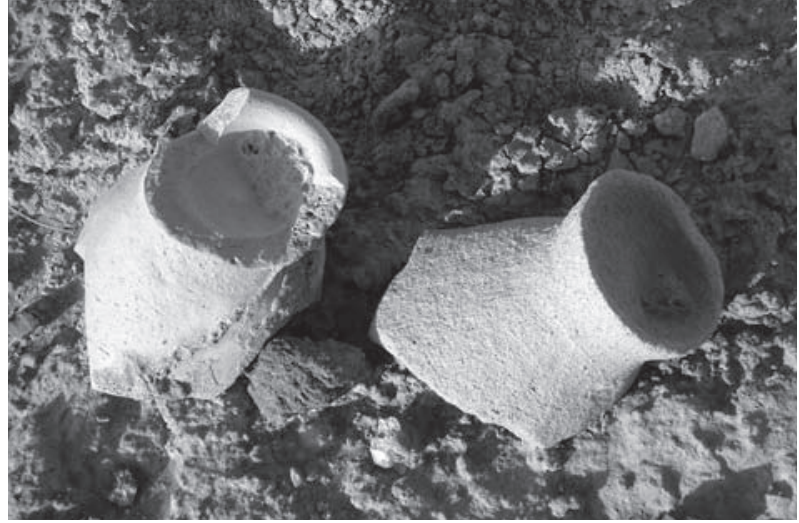

Fig. 6. Shahdad 2009, ring foot fragments of the same conical Aliabad-Iblis IV vessels (see Fig. 5). Similar sherds are very common on the surface of Mound I.

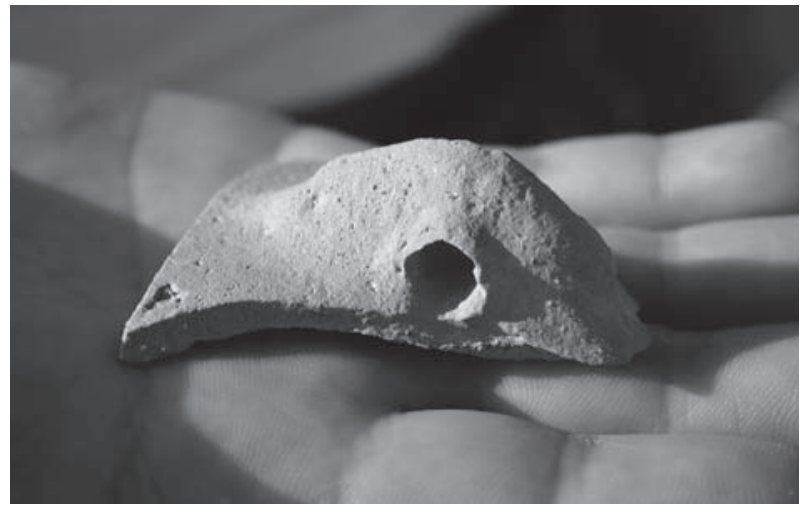

Fig. 8. Shahdad 2009, ear-like lug from a restricted jar.

\section{EXCAVATION AND STRATIGRAPHY OF THE SHAHDAD FLAGON}

The vessel found at Shahdad contained a soft and dark substance that sloped towards the vessel mouth. In order to control the effects of alteration, this was gradually excavated stratigraphically with a steel scalpel, following its variable compactness and its changes in colour (Fig. 10). Each layer was considered an alteration stage of the original substance, and separately sampled and labelled. Any contact with the bare hands was carefully avoided. Layer 1 was dark grey, soft and powdery; layer 2 equally soft and powdery, but slightly darker in colour; layer 3 was reddish-grey and its grain size seemed to increase; layer 4 was brownish

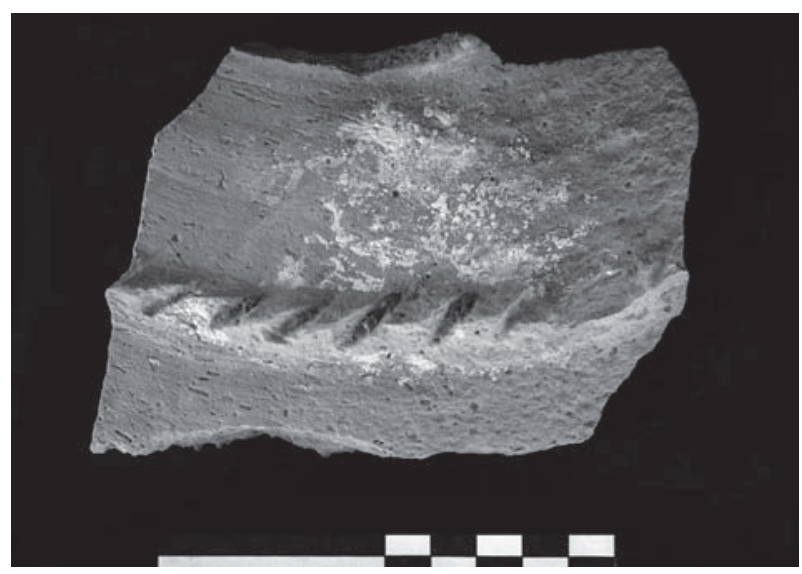

Fig. 7. Shahdad 2009, shoulder fragment of a large necked jar with a horizontal impressed ridge.

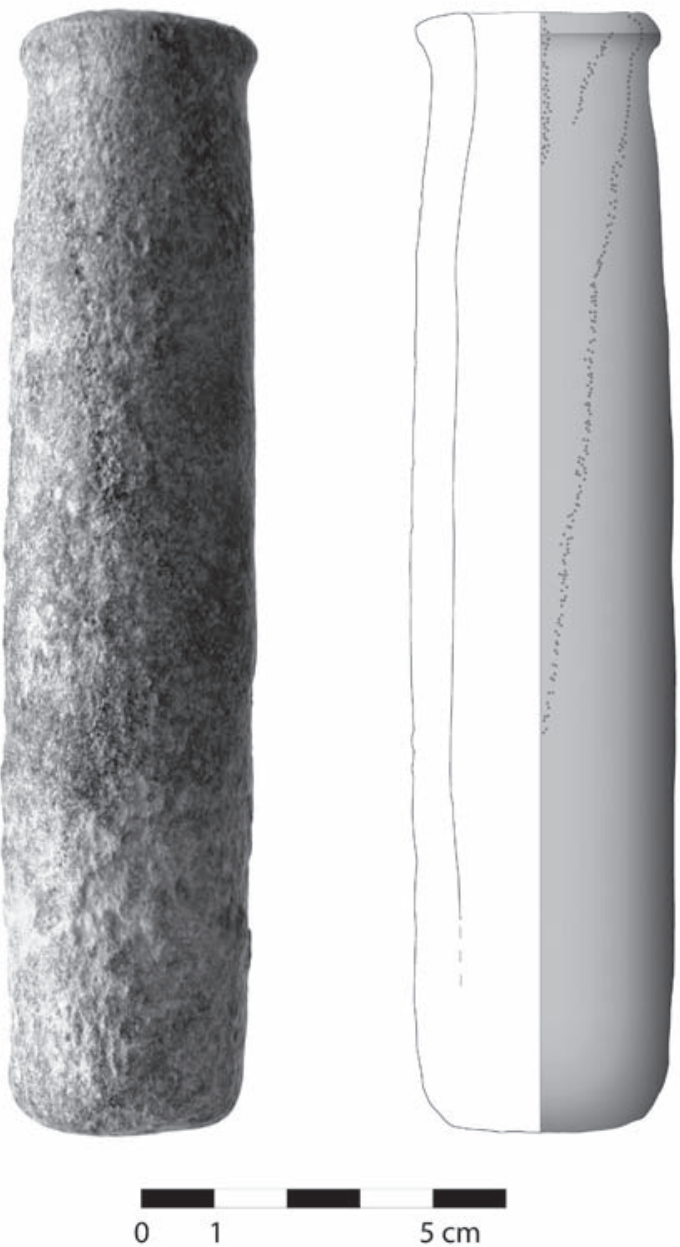

Fig. 9. Shahdad 2009, picture and drawing of the cosmetic flagon in chlorite (F. Desset). 

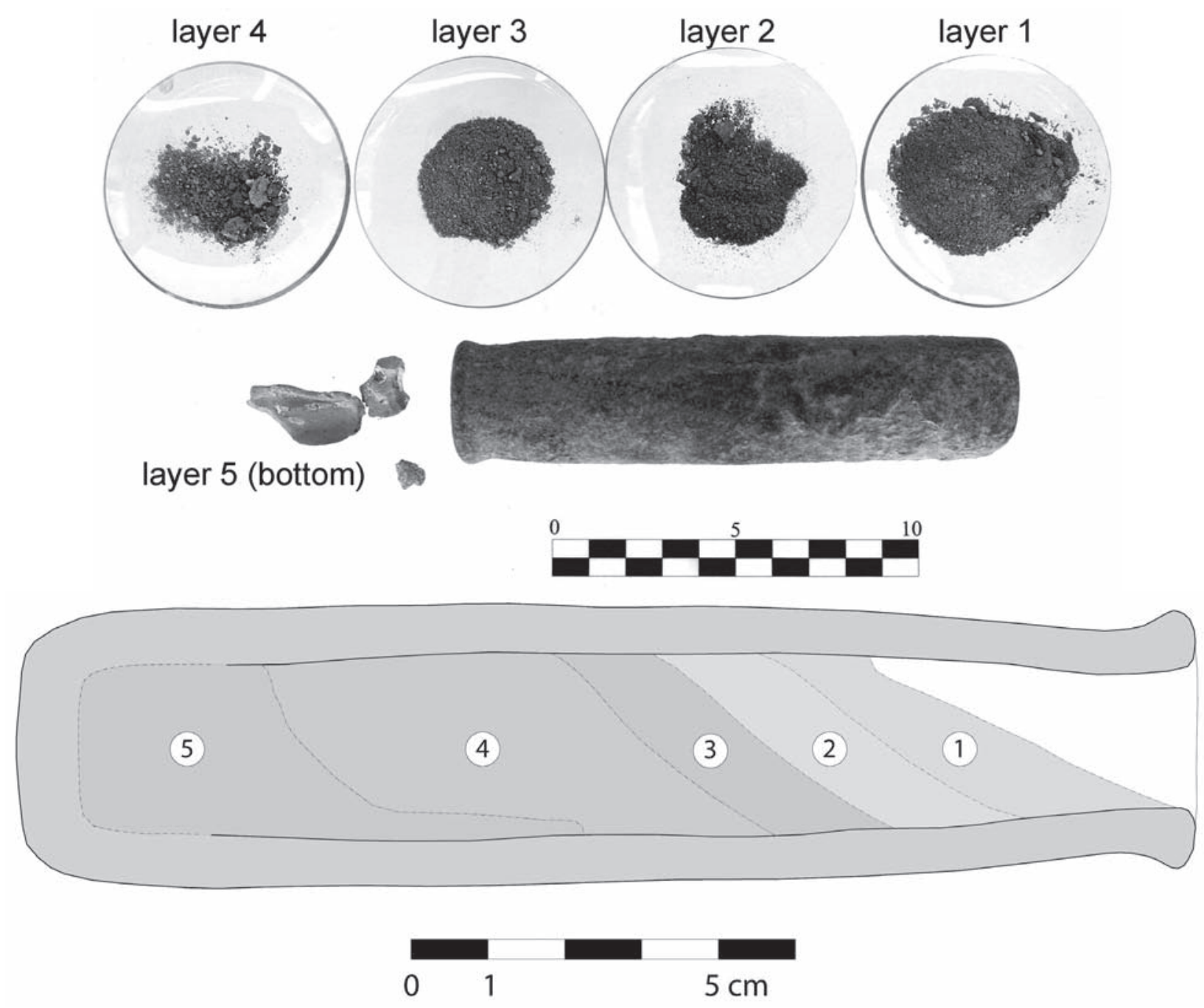

Fig. 10. The content of the chlorite flagon recorded in section (M. Vidale, F. Desset) with the material sampled from each layer.

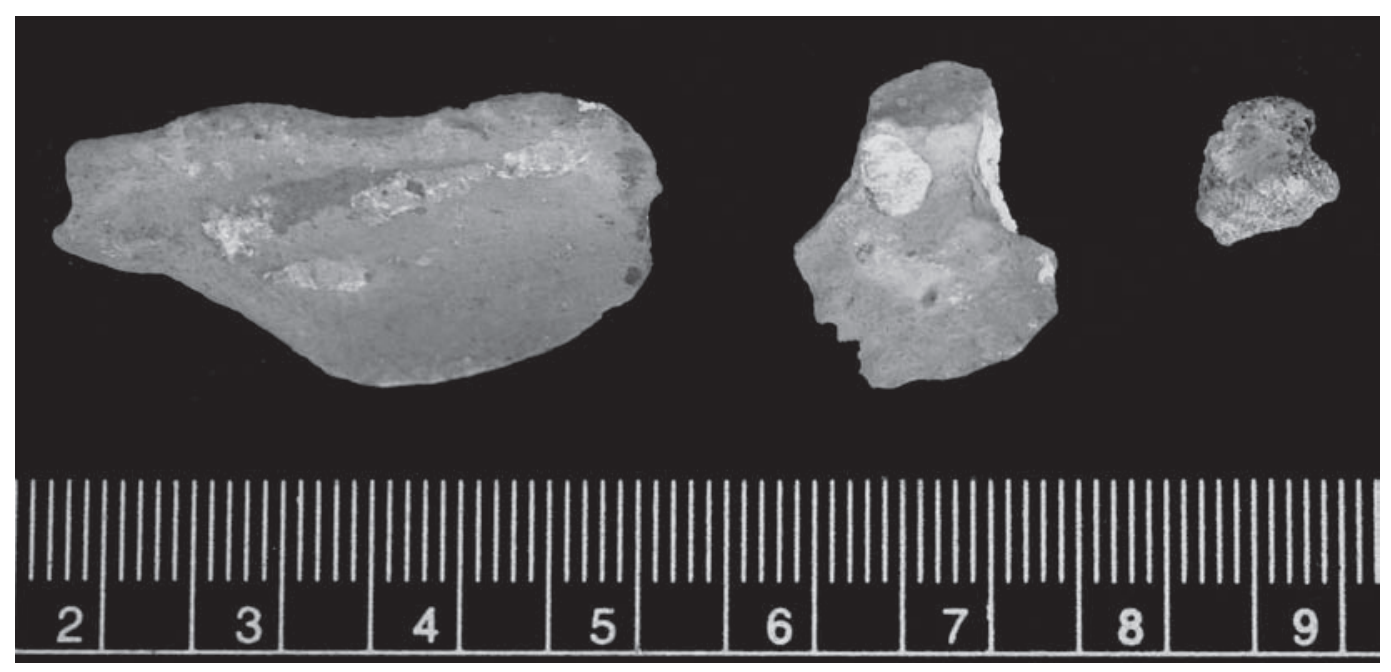

Fig. 11. The samples of layer 5 in detail. 
in colour, more compact, and was removed in coarser grains and crumbled particles. Finally, layer 5, at the bottom of the filling, was pinkish grey, compact and very hard to remove; the flakes we took were levered off from the thinner upper extension visible in the section (Fig. 11).

\section{ANALYSES}

\section{III.1. XRD and SEM-EDXRF analysis}

XRD analysis was carried out in order to characterise each of the five layers. The compositions (Fig. 12) are almost identical, with prevalence of cerussite $\left(\mathrm{PbCO}_{3}\right.$, best match with PDF 70-2052 and 76-2056). Layer 5 (Fig. 12) reveals a single composition with $\mathrm{PbCO}_{3}$ and a minimal trace of quartz; besides cerussite, the other samples (Fig. 12), show the main peak of hydrocerussite $\left(\mathrm{Pb}_{3}\left(\mathrm{CO}_{2}\right)_{2}(\mathrm{OH})_{2}\right.$, best match with PDF 10-401). Moreover, layers 1 to 4 (Fig. 10) show traces of quartz and clinochlore $(\mathrm{Mg}, \mathrm{Fe})_{6}(\mathrm{Si}, \mathrm{Al})_{4} 0_{10}(\mathrm{OH})_{8}, \mathrm{PDF}$ 29-701). Quartz presumably entered the receptacle mainly in the form of fine aeolian and/or sedimentary sand, ${ }^{9}$ and clinochlore evidently came from the decay of the inner wall of the stone vessel. Layer 5 in the bottom (Fig. 10) contains only pure lead carbonate, without weathering or extraneous solid inclusions, and the other layers are only slightly affected by chemical alteration. 10

Observed using a SEM at low magnification, layer 5 (Fig. 13) is an homogeneous, compact, fine grained and slightly porous lead compound with secondary peaks of calcium, carbon, aluminum and traces of sulphur. In a spot analysis, the microprobe found localised traces of copper, which is probably exogenous to the

9 Even though it is not excluded that a very low amount of quartz was associated to the low quantities of calcium found by the means of FTIR and SEM-EDXRF, being purposefully added to the lead carbonate, for example in form of a white clay or marl.

10 Experimental studies like Mercy et al. 1998, Martinetto et al. 2002, Welcomme et al. 2006 showed that the formation of cerussite depends upon local $\mathrm{pH}$ and $\mathrm{P}_{\mathrm{O}_{2}}$ conditions, directly affecting each solubility product. Even though the substance might have originally contained both cerussite and fractions of hydrocerussite, its final state may be the output of complex alteration processes (partially reflected in the flagon's stratigraphy) impossible to reconstruct in greater detail. substance (see below). At higher magnification (Fig. 14), this amorphous phase shows localised tabular and complex wide crystals (c. 5 to $50 \mu \mathrm{m}$ wide). At the centre of Fig. 14, the crystal of about $5 \mu \mathrm{m}$, at the top right, shows a trigonal symmetry marked by the basal face (rectangular shape, (001) form), with the emergence of a singular crystallographic axe; the adjacent face, in contrast, has the shape of an irregular hexagon, and belongs to the rhombohedral (112) form. All forms are fully compatible with cerussite.

In this mass are evenly scattered minute compact crystals, with a marked and intense cubic cleavage, of galena (PbS), c. 50 to $200 \mu \mathrm{m}$ in length (Fig. 15). ${ }^{11}$ These tiny galena particles, resulting from metallogenetic processes, are below the detection limit of XRD, but were identified by SEM-EDXRF elemental analysis. They are surrounded by a homogeneous film of molten lead, about 10-20 $\mu \mathrm{m}$ thick. Microprobe analysis shows that these galena crystals bear some sulphur on the surface, but the same element is absent in the molten outer film, which is chemically identical to the groundmass. This confirms the pyro-technological origin of the base material, because sulphur was gradually removed by heating. In other words, these crystals are probably microscopic residues of the ore which survived in the following transformation stages of this substance. Pores might have contained tiny vegetal particles, still present in the lead mass as recognisable inclusions (Fig. 16).

\section{III.2. TGA analysis}

To determinate the amount of lead carbonates in the sample we ran a TGA of layer 4 , altered but immediately on top of the solid substance $\left(20^{\circ} \mathrm{C} / \mathrm{min}\right.$ and $100 \mathrm{~cm}^{3} / \mathrm{min}$ of nitrogen flow) (Fig. 17). Lead carbonates, by thermal decomposition, are transformed in lead oxide loosing between 200 and $400^{\circ} \mathrm{C}$, in a complex way, water and carbon dioxide, in the amount of $13.7 \%$ for basic lead carbonate (hydrocerussite) and $16.5 \%$ for lead carbonate (cerussite) respectively. Above $900^{\circ} \mathrm{C}$ lead compounds start to volatilise. ${ }^{12}$ Although not identified by the means of XRD and FTIR, the TGA curve shows that the sample is made of $c .4 \%$ of calcium carbonate, confirming the presence of a certain amount of

\footnotetext{
11 These crystals are apparently identical to those described in Grüner 2002, Walter et al. 1999 and Law 2011.

12 Hatakeyama and Zhenhai Liu 1998.
} 

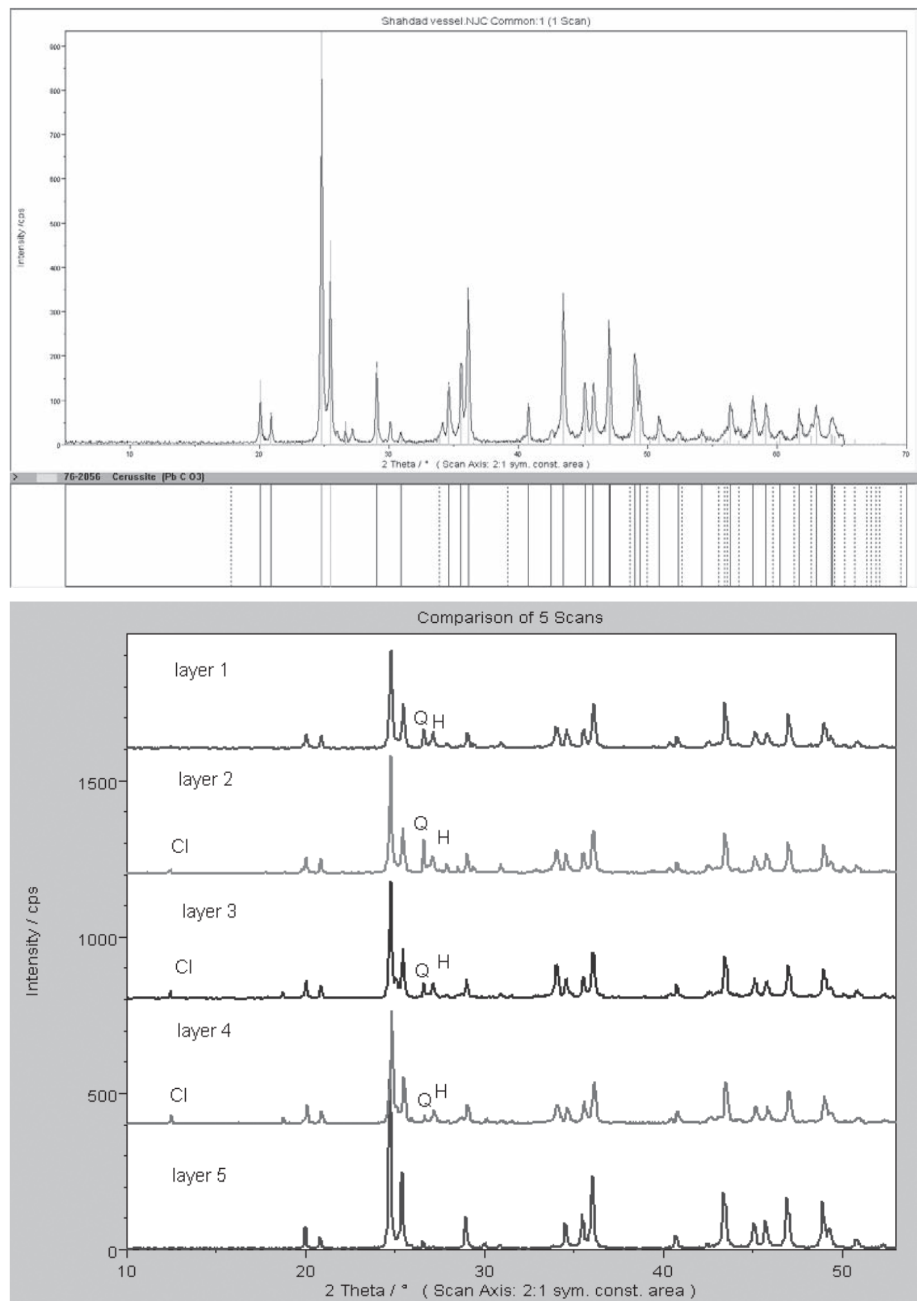

Fig. 12. XRD scan of layer 5, showing the match with PDF 76-2056 (PbCO , cerussite) and comparison among the XRD scans of the five layers, showing the cerussite content and minor variations due to weathering and chemical alteration. $H=$ hydrocerussite; $\mathrm{Cl}=$ Clinochlore; $Q=Q$ uartz. The rest of the peaks identify cerussite. 


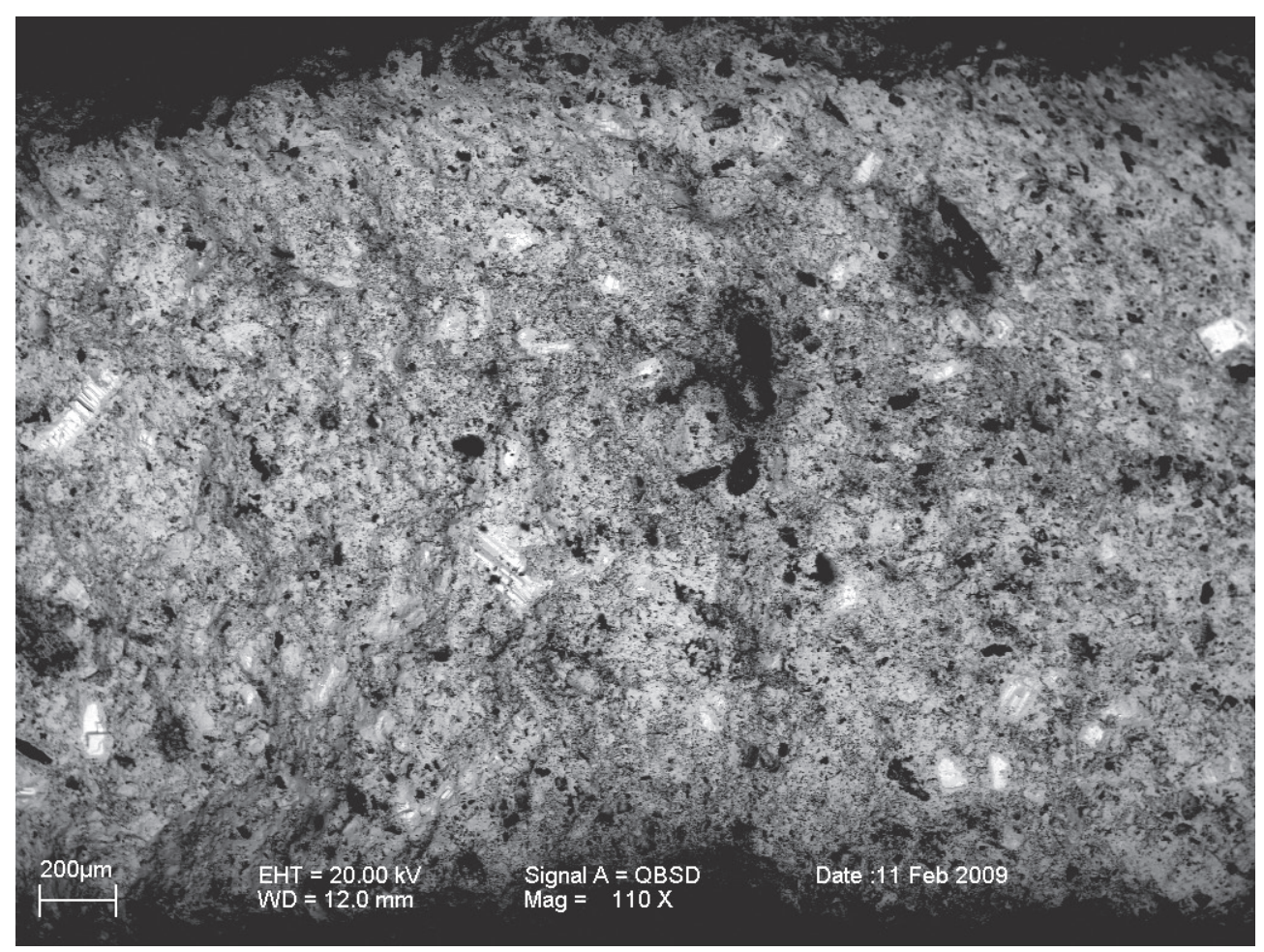

Fig. 13. SEM picture of a sample of layer 5, in fracture (110 X).

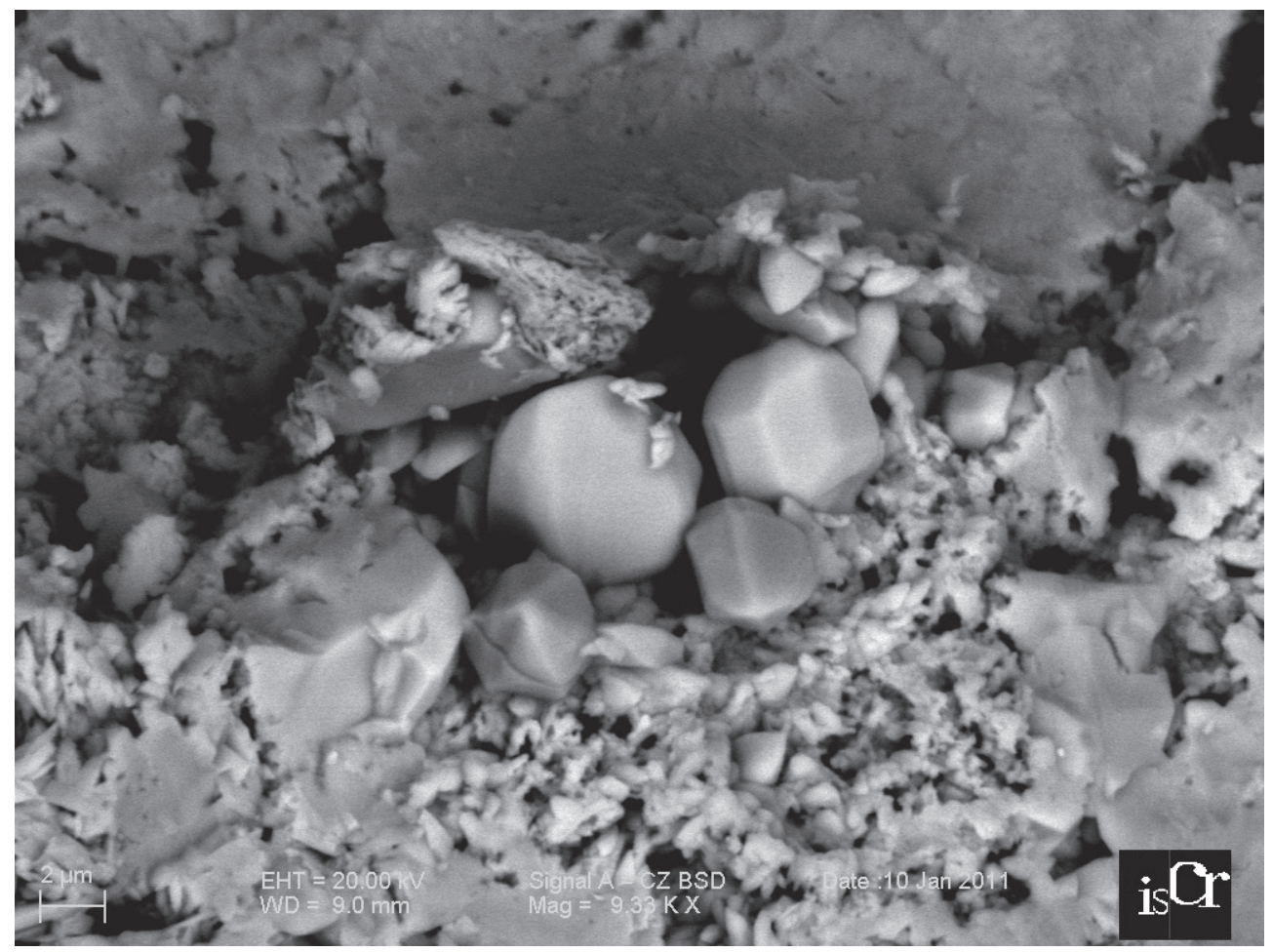

Fig. 14. SEM picture of a sample of layer 5, showing detail of cerussite crystals (9000 X). 


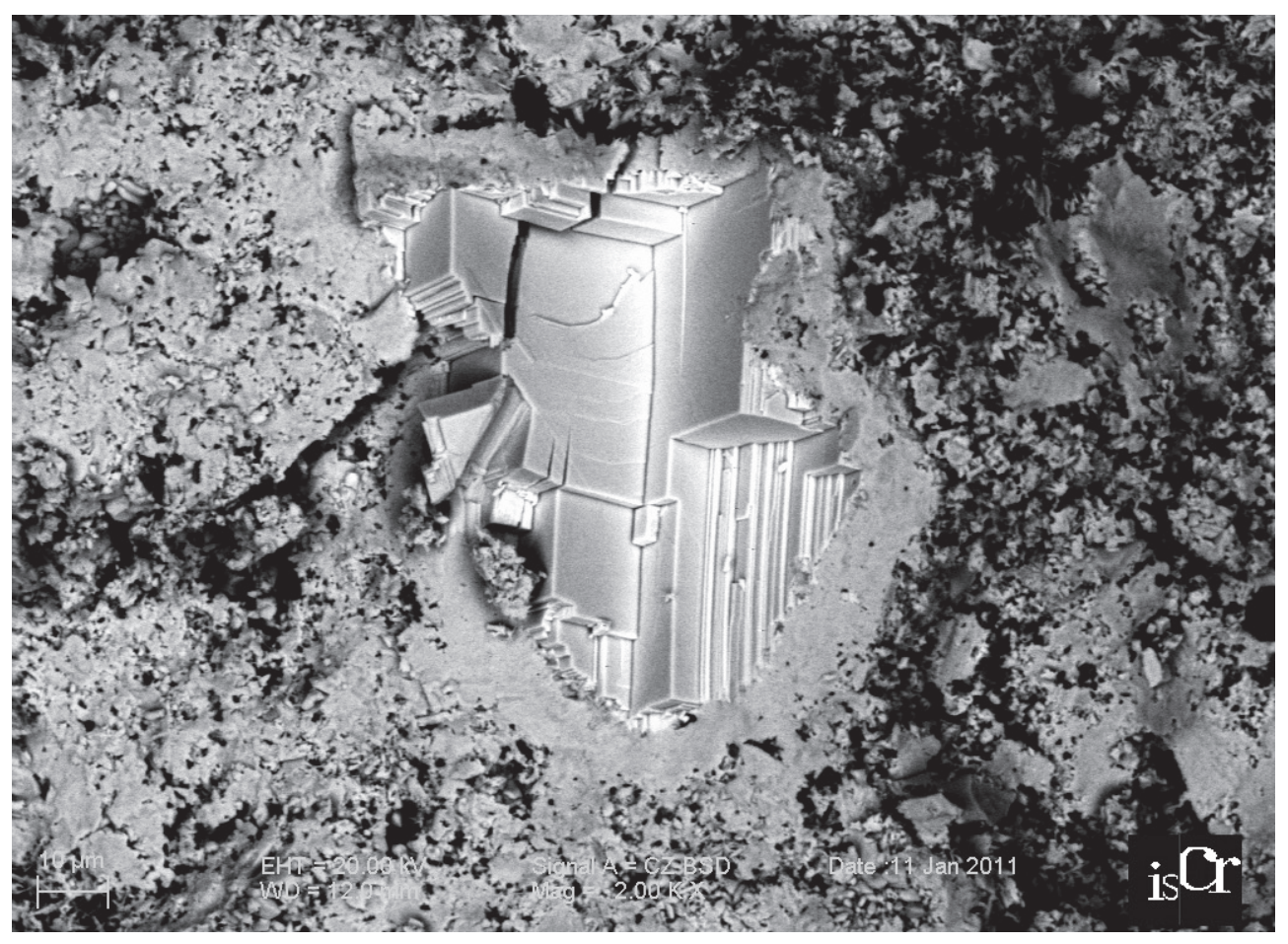

Fig. 15. SEM picture of a cubic crystal of galena $(\mathrm{PbS})$ in layer 5. These crystals are c. 50 to $200 \mu \mathrm{m}$ in length and surrounded by a thin layer of molten lead free from sulphur. In this study they are considered as residues of the mineral smelted to obtain the lead from which carbonates were obtained by the means of a chemical processing.

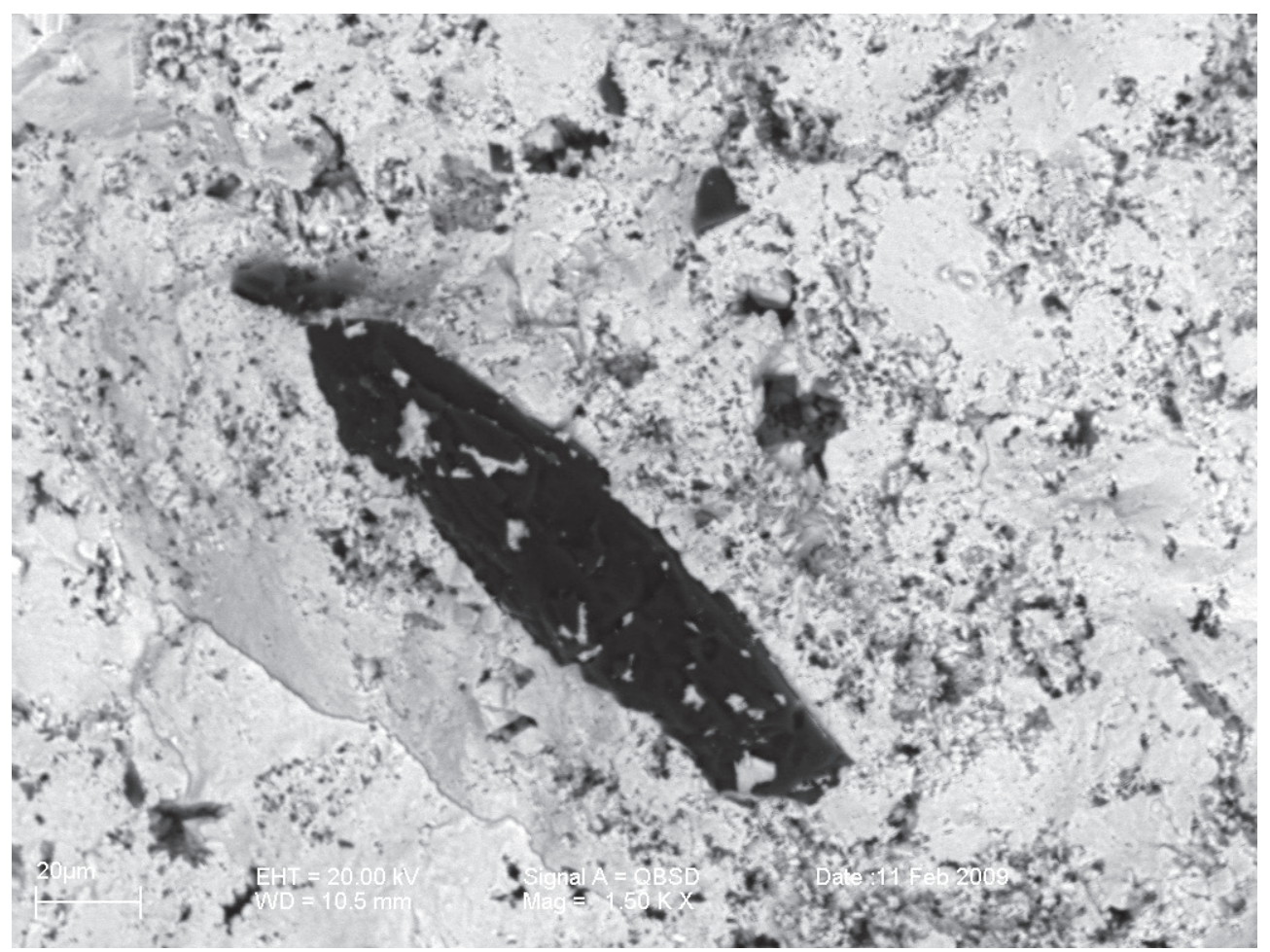

Fig. 16. SEM picture of a vegetal micro-inclusion in layer $5(1500 \mathrm{X})$. 


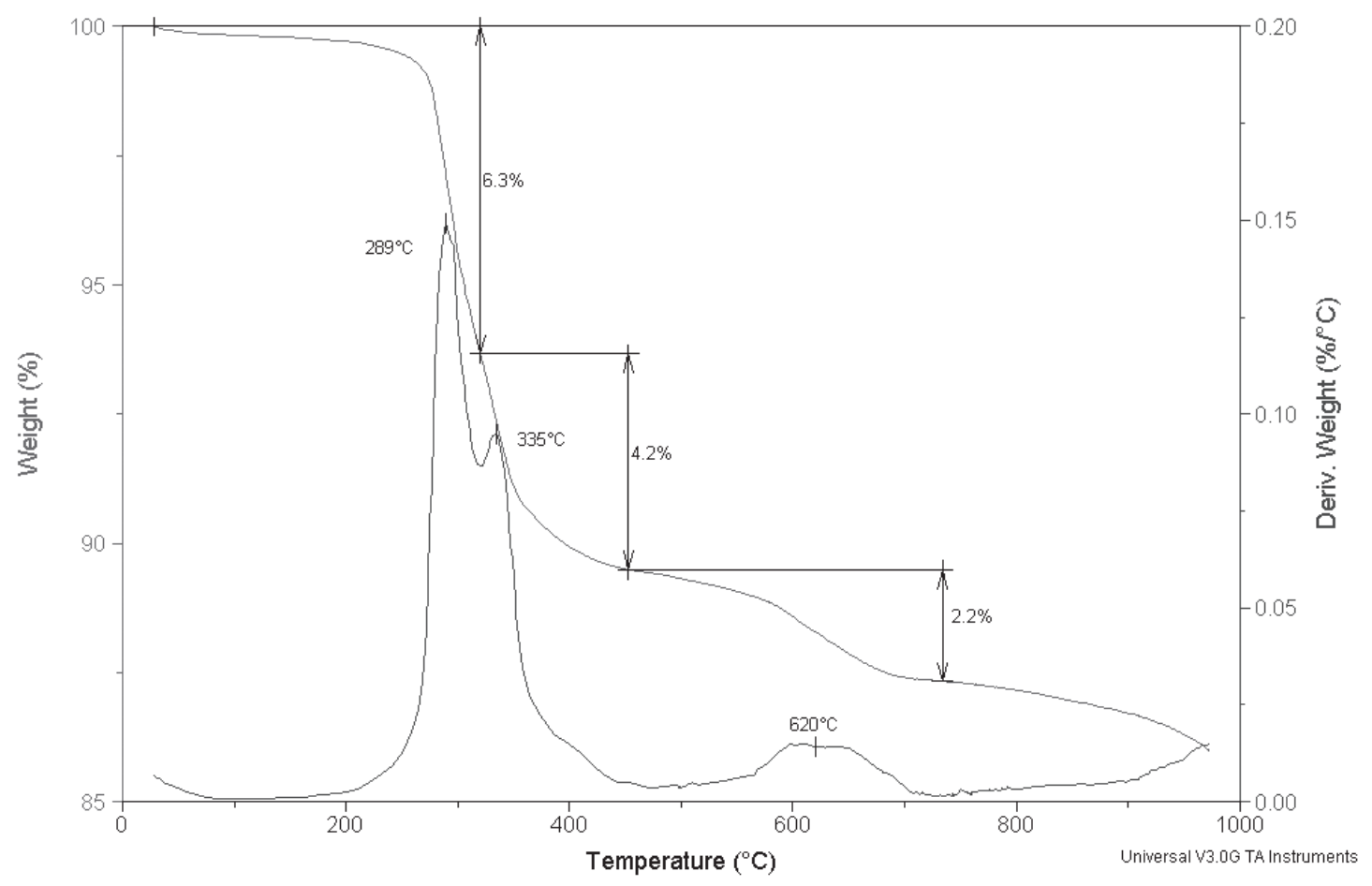

Fig. 17. TGA curve of layer 4, the weight loss showing that lead carbonates are present in the sample for a value included between 63 and $76 \%$ (for detail see text).

calcium detected by the SEM-EDXRF analysis (weight loss above $600^{\circ} \mathrm{C}$ ).

\section{III.3. FTIR, GC and GCMS analysis}

In order to identify any organic components, a sample fraction from layer 413 was extracted in dichloromethane. The solution was deposited on a $\mathrm{KBr}$ disk and, after evaporation of the solvent, was analysed by infrared spectroscopy (FTIR). The spectrum (Fig. 18) could not be interpreted univocally due to the low amount of organic matter. The signals at 2853, 2923, $2954 \mathrm{~cm}^{-1}$ (C-H stretching) and at $1737 \mathrm{~cm}^{-1}(\mathrm{C}=\mathrm{O}$ stretching) suggest the presence of traces of oils or wax.

13 Layer 4 was selected for this and other tests (see above) as representing an average sample fraction of the whole content, being relatively well protected in the core of the fill but with a loose consistency on top of the solid layer 5 .
To look for organic compounds possibly contained in the substance, three samples $(c .0 .5 \mathrm{~g})$ were extracted by ultrasonic action with three aliquots of dichloromethane:methanol $(2: 1 \mathrm{v} / \mathrm{v} ; 5 \mathrm{ml})$, silylated and analysed by gas chromatography (GC) and gas chromatography-mass spectrometry (GC-MS). These samples came from the top of the filling (layer 1), from the lower-middle part (layer 4) and from the solid grey substance recovered from the bottom (layer 5), respectively. The amount of lipid in the sample was quantified with reference to internal standards (Table 1).

TABLE 1. Amount of lipid found by GC-MS in layers 1,4 and 5 .

\begin{tabular}{|l|l|c|}
\hline Code & Layer and description & Lipid ug/g \\
\hline 4192 & top, layer 1 & 275 \\
\hline 4190 & lower-middle, layer 4 & 161 \\
\hline 4189 & bottom, layer 5 & 66 \\
\hline
\end{tabular}




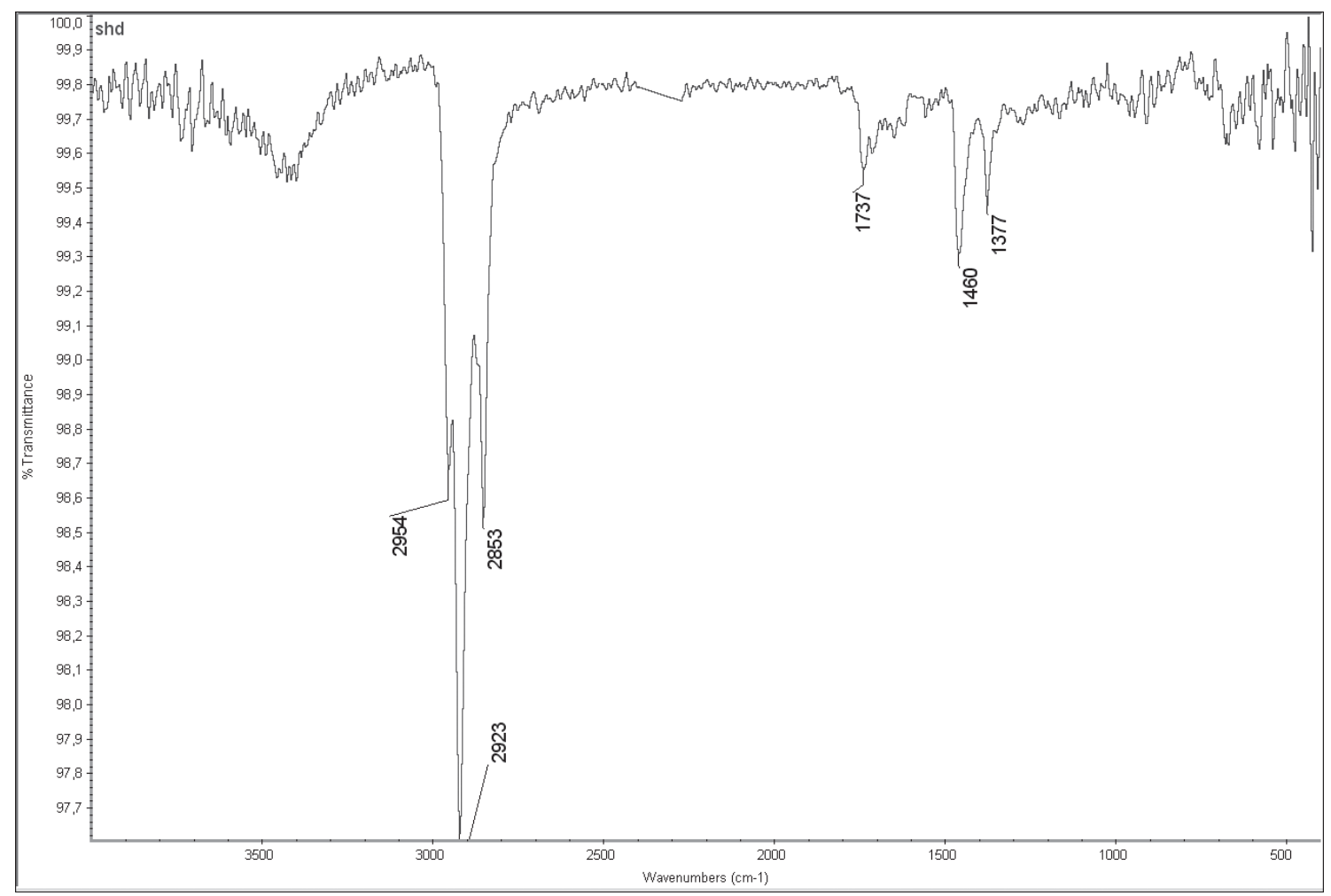

Fig. 18. FTIR spectrum of layer 4. The signals at 2853, 2923, $2954 \mathrm{~cm}^{-1}\left(\mathrm{C}-\mathrm{H}\right.$ stretching) and at $1737 \mathrm{~cm}^{-1}(\mathrm{C}=\mathrm{O}$ stretching) suggest the presence of traces of oils or wax, possibly added to the cosmetic as a binder.

The low amount of lipid on the sample from layer 5 prevents easy interpretation as, despite its sealed context and the evidence that weathering (as established by archaeological observation) was limited to the topmost layer, contamination from the narrow mouth of the flagon cannot be completely ruled out, as the depositional history of the stone container is unknown. GCMS analysis of this sample (4189, layer 5 ) revealed the very low amounts of fatty acid methylester and aromatic hydrocarbons. 8-methylcoumarin was noted in this sample $(\mathrm{m} / \mathrm{z} 160,132,104,51)$. This is an aromatic compound derived from a range of plant species. It may be derived from other compounds, e.g. cinnamic acid derivatives, or be the natural compound. As 8-methylcoumarin was not found in the upper part of the filling (layer 1, most affected to weathering and sedimentary contamination), it might be endogenous to the sample, i.e. derived from the original ingredient of the white lead substance. However, apart from this, the chromatograms obtained from the upper "fill" layers (4192, layer 1, and 4190, layer 4), were qualitatively near identical to the grey substance in the bottom layer (4189, layer 5).

\section{DISCUSSION}

The analytical work so far reported identifies the substance of the Shahdad chlorite flagon as a mixture of lead carbonates (about $70 \%$ of the total). Lead carbonates have a well-known role in the history of cosmetic technologies as the base component of white facial make-ups. ${ }^{14}$ However, in many cases it was not clear whether lead carbonates found in ancient cosmetics were intentionally produced with a wet chemical process or were a post-depositional transformation of more common lead sulphides like galena, generally used in the past, as in contemporary traditional cosmetics as dark eye-liners $(k o h l)$.

When galena-based kohls found in archaeological digs are not transformed in burial, there is little doubt about their nature and function. When late Roman to early medieval "kohl tubes" from Palestine were found to contain only galena, the content was considered altered kohl. ${ }^{15}$ But if sulphides and carbonates are

14 Nriagu 1983.

15 Blanchard et al. 1992. 
encountered in the same substance, like in the Shahdad cosmetic, the question gets thorny. In similar cases analysts constantly wrestled with difficult distinctions between natural lead minerals, lead carbonates forming in burial after the transformation of lead sulphides and similar substances, and carbonates artificially produced through wet chemical processing.

For example, the content of another late Roman double-tube glass flask, analysed by XRD and SEM, ${ }^{16}$ revealed anglesite and cerussite together with galena, and here the two former phases were considered as alterations of the last. The content, dark grey, with metallic sheen, appeared as "...very fine grained groundmass with hydiomorphic intergrown cubes of galena". ${ }^{17}$ A very similar structure appears in some ancient Egyptian cosmetics and is described as follows: "Compounds of lead and chloride are aggregated with cubic crystals of galena that have well developed faces free of alteration". 18 These galena inclusions are very similar to the galena crystals in a wulfenite-graphite heterogeneous matrix found in a grave at Harappa 19 and in the substance discussed in this paper.

Let us consider the problem of post-depositional alteration in closer detail. Cerussite and hydrocerussite are common secondary transformation products, both in the oxidised portions of lead ore and of castworked lead objects (e.g. when carbonate or salt-rich solutions circulate in modern lead pipes). ${ }^{20}$ In deserts, such secondary minerals form on lead objects affected by limited but continuous wetting-drying cycles, when soils are rich in chloride anions due to local evaporitic processes. ${ }^{21}$ On lead buried in less extreme environments, $\mathrm{CO}_{2}$ in ground water or surrounding aqueous solutions forms small amounts of cerussite and hydrocerussite through surface dissolution. In burial, the precise ratio of each $\mathrm{Pb}$ carbonate depends upon micro-environmental factors, kinetics being affected by the $\mathrm{pH}$ and Eh of the local soils. This clearly supports the possibility that in many cases lead carbonates in ancient cosmetics are indeed secondary transformations of galena powders.

However, cerussite and hydrocerussite have been analytically identified as ceramic pigments used in the

\footnotetext{
6 Grüner 2002.

Grüner 2002: fig. 5, 81.

Walter et al. 1999: fig. $1 \mathrm{~b}$ and its caption.

Law 2011: fig. 12.32E.

Kim and Herrera 2010.

Dermatas et al. 2004.
}

fourth century $\mathrm{BC}, 22$ and as the base material of white make-ups from the Hellenistic-Roman period.23 Ultimately, the high number of ancient cosmetics made of unaltered galena detected in the past in Egypt and in the Near East - in conditions of strong aridity - and in many other locations across three thousand years, makes it unlikely that lead carbonates are always secondary transformations of galena-based eye liners. Sources of the first century BC-first century AD 24 reveal that in Roman times white substances made of lead carbonates were intentionally and artificially produced. Lead oxide was ground and diluted into salted and sometimes carbonated water, and eventually added to black galena. White precipitates thus synthesised from galena were reputedly good for skin care and eye protection, from infections or from the sun. Cerussite or white lead was prepared by exposing lead sheets to acetic acid. Lead acetate formed first, then reacted with $\mathrm{CO}_{2}$ from the atmosphere to form lead carbonates (according to empirical data, the ratio Pb-carbonate/ $\mathrm{Pb}$-hydroxylcarbonate is about 70 to $30 \%$ ). Frequently quoted contemporary ancient authors (Plinius, NH 4.175 and others including Vitruvius, Dioscorides and Celsus) describe in detail, with technical variants, the production of lead acetate and then carbonates by exposing lead sheets to vapours of vinegar and $\mathrm{CO}_{2}$, produced by decomposing dung and scraping off the shiny white efflorescence. ${ }^{25}$ In the Greek-Roman world artificial white lead was the commonest facial make-up, the background colour of which strongly contrasted with galena-based dark eye-liners.

\section{IV.1. Wet chemical processing of lead in the Bronze age}

But how old exactly are these technologies of wet chemical processing? Have they been positively identified in the Bronze age of the Near East and southern Middle Asia? Graham found lead carbonates in two cosmetic pigments - light blue and black - from the

Eastaugh et al. 2004: 91, s.v. "Cerussite".

23 Dayagi-Mendels 1993; Welcomme et al. 2006. Donato et al. 1975: 78-79 report that while sources of the fourth century BC like Aristophanes and Xenophon mention a widespread use of white lead facial make-ups, other authors would reveal since the second century AD a shift to white foundations made of silicates, perhaps because the harmful effects of lead on human health had been gradually realised.

24 Reviewed in Walter 1999; Walter et al.1999.

25 Colombo 2003: 78-79. 
Royal Cemetery of Ur (about 2400-2300 BCE), but stated that they had formed in the ground through the alteration of lead oxides. ${ }^{26}$ Bimson analysed some light coloured pigments from the same site, finding hydroxy-apatite from calcined bones, and stated that cerussite might have been added to green pigments for diluting the hue. ${ }^{27}$ The evidence here is still partial and not conclusive.

In Egypt, where cosmetics were frequently found in ancient burials and the generally dry climate makes strong post-depositional alteration less probable, the evidence of intentional manufacturing of artificial lead carbonates has been considered very limited. For example, A. Lucas reported eye-liners or kohl made of malachite or galena and mentioned as face paints red iron oxides, particularly hematite. ${ }^{28} \mathrm{He}$ noted the prevalence of ground galena (forty out of sixty-one, about $65 \%$ of the cases), followed by manganese oxide, brown ochre, malachite and in a few cases lead carbonate, applied with water or a gum. Fatty matter was apparently absent. ${ }^{29}$ Lead carbonates were never used in Egyptian painting, ${ }^{30}$ nor is cerussite listed in an updated inventory of white materials including calcite, gypsum and huntite, powdered shell and cuttlefish bone, powdered and calcined bone. 31

Recent studies are, however, changing this picture radically. When gas chromatography, FTIR spectrometry and powder XRD were used on forty-nine ancient Egyptian cosmetics at the Louvre, one dating to the early second millennium BC, 32 about $75 \%$ of the analysed cosmetics turned out to include lead carbonates. Animal grease had been added as a binder for crushed ore of black galena and cerussite, this latter

26 Graham in Woolley 1934: 248.

27 Bimson 1980; see also Moorey 1999: 138-39, and Benoit 2010: 314.

28 Lucas 1948: 99-104.

29 In the last century, another kohl material was carbon (lamp soot) sometimes mixed with galena. Eighteen contemporary kohl samples purchased in Cairo were recently analysed using X-ray diffraction (XRD) and scanning electron microscopy (SEM), as reported in Hardy et al. 2004. Galena was the most common component (six cases, 30\% of the cases), followed by carbon, calcite, cuprite, goethite and talc mixed with carbon (for contemporary kohls in the Middle East and their poisonous effects see also Parry and Eaton 1991; Rahbar et al. 2002; Cartwright-Jones 2005; FDA US Food and Drug Administration 2006).

30 Colombo 2003: 38-40; Mariottini and Vigliano nd.

31 Lee and Quirke 2000: 114-15.

32 Walter 1999; Walter et al. 1999. entering the composition of grey-to-white make up. Other white constituents were laurionite $(\mathrm{PbOHCl})$ and phosgenite $\left(\mathrm{Pb}_{2} \mathrm{Cl}_{2} \mathrm{CO}_{3}\right)$. If in contact with carbonated and chlorinated waters or wetting cycles, these complex minerals might form by chemical alteration and ageing of the analysed cosmetics. As no evidence of alteration was found in the forty-nine recipients, laurionite and phosgenite were, however, interpreted as intentionally manufactured. Thus, these studies unexpectedly revealed that wet chemical processing was common in the Egyptian courts of the early second millennium $\mathrm{BC}$.

Moreover, there is growing evidence that the production of artificial lead compounds as colouring substances was common in the third millennium BC as well, from the Mediterranean to the Indus. At the third millennium BC settlement of Akrotiri on Thera (Greece), stone tools with traces of lead oxides were used in preparing pigments. ${ }^{33}$ Cerussite make-ups might have been largely in use in the cities of the Iranian plateau of the third millennium BC, as many graves of the cemeteries of Shahdad (second half of the third and beginning of the second millennium BC) are said to have contained white make up with lead or silver powders. ${ }^{34}$ Cerussite was also identified in stone and ceramic receptacles both at Mohenjo-Daro ${ }^{35}$ and Harappa, 36 the early urban settlements of the Indus Civilisation, dated c. 2600-1800 BC.

White cosmetics found in the graves of Adji Kui in Margiana, Turkmenistan (late third or early second millennium BC) included apatite, gypsum and calcite, but also cerussite and laurionite. ${ }^{37}$ Recent analyses of cosmetic residues within receptacles of the third-second millennia BC from Eastern Iran and Central Asia at the Louvre, carried out by E. van Elslande and others, would also reveal a deliberate use of (artificial) cerussite. 38

33 Sotiropolou et al. 2010.

34 Yaghmaie 1999, quoting M.A. Kaboli, one of the excavators of Shahdad; but no analytical evidence is provided.

35 Sana Ullah 1931 and Mackay 1938: 665

36 Vats 1940: 312. Results summarised in Chandra 1973 and Subbarayappa 1999. See also Law et al. 2010 and Law 2011: 426-32, figs. 12.28, 12.29.

37 Rossi-Osmida 2007: 266-68, but the documentation is poor and confusing.

38 Benoit 2010: 314. 


\section{CONCLUSIONS}

\section{V.1. Summary and final remarks about the content}

The Shahdad substance was sealed in the bottom of a narrow, impermeable and chemically stable stone receptacle, and the XRD patterns of the five layers (Fig. 12), in spite of an evident textural and chromatic alteration, do not show major chemical variations in the bulk. On the contrary, the less altered bottom layer 1 only contains pure lead carbonate, and there was no evidence of growing amounts of galena as we dug into the core of the content. Galena crystals visible in the cerussite ground mass, doubtless exposed to firing and melting on the surface with a gradual loss of their sulphur content, are interpreted as original inclusions of the lead slabs or lumps treated for the chemical extraction of white lead carbonates. In short, ${ }^{39}$ the Shahdad substance had been most likely obtained with an artificial process similar to those described by the ancient Greek-Roman authors.

The search for fatty substances and other organic components was not conclusive, due to their low amounts and the impossibility of assessing the risks of contamination by solutions from the surrounding environment. FTIR analysis showed limited residues of fatty substances, and if 8-methylcoumarin in the lowermost layer is actually endogenous, it might have been introduced as the ground herb or spice whose fragments are still visible in the substance (Fig. 16). Coumarins in cosmetics might have had a purely aromatic or even a medical function. 40

The recipe included silicates and calcium compounds (from a fine, light clay?), an unknown vegetal

39 Contra Grüner 2002 and other previous interpretations.

40 See Feurer 1974. Coumarins are present in species of Umbrelliferae (Apiaceae), Fabaceae and Rubiaceae (Dewick 2009). Among Umbrelliferae range carrots, cumin (Cumynum cyminum, used at the site of Shahr-i Sokhta, in the Iranian Sistan, in the third millennium BCE, see Costantini 2003); Centella asiatica is still used for the treatment of venous and skin diseases, see Indena 2011. Other candidates could be Anthoxantum odoratum (the vanilla-scented sweet vernal grass); cinnamon (different species of the families Lauraceae and Fabaceae); galium odoratum (or woodruff, family Rubiaceae); species of the genus Verbascum (commonly mullein, family Scrophulariaceae) and Lavandula (commonly lavender, family Lamiaceae). Coumarins have been also found in date palm leaves, as reported in Mohamed et al. 2001: 5-11; and Morton 1987: 10. component, small amounts of organic materials like binders (oils or wax), and possibly an aromatic ingredient. Faint traces of copper may have been left by a copper applicator like in a flagon from Palestine. ${ }^{41}$

\section{V.2. Historical implication of this discovery}

This cerussite-based face-paint or foundation 42 appears to have been a kind of prehistoric safidāb (literally "white water", lead-based whitening face make-up), according to Qajar period texts describing the haft qalam ārāyesh, also haftvand or har haft ("all seven together"), the full cosmetic kit for women. ${ }^{43}$ Were it of the late fourth (as suggested by the surface context) or third millennium BC, it is one of the earliest products of this type ever identified in the Near East and Middle Asia. In ancient Egypt and Mesopotamia, the role of lead-based pigments and their technologies were underestimated, until new research ${ }^{44}$ placed the beginning of wet chemistry processes and of complex cosmetology in Egypt in the early second millennium BC. We are currently realising that cosmetics made with artificial lead carbonates were widely used in the third millennium $\mathrm{BC}$ from the Indus Valley to the Iranian Plateau, Central Asia and perhaps Greece. The Shahdad flagon might consequently re-date the innovation to the late Chalcolithic age, at the time of the so-called "Uruk expansion". 45

\section{V.3. Final consideration on cosmetology}

Cross-cultural factors of facial attractiveness 46 include youthfulness, skin homogeneity and luminance, conformity or similarity of the face to the population average, sexual dimorphism and bilateral symmetry of the

41 Grüner 2002; see also the Bronze-age burials at Shahdad and in Margiana, where many flagons still retained their pin-applicator: Pottier 1984: pl. XVIII, 119; XIX, 127; XXI, 155; XXII, 160; XXIII, 164 and 165; Hakemi 1997: gr. 113, 269; Rossi-Osmida 2007: fig. 1, 262; in the same volume, 288; Farmanfarmaian 2003: pl. 4.

42 Eastaugh et al. 2004: 91; Gettens et al. 1967.

43 Farmanfarmaian 2000; 2003.

44 Walter et al. 1999; Ungar et al. 2002.

45 Alden 1982; Algaze 1993; 2008; Moorey 1999: 93; Pollock 2006: 78-116; Potts 1999.

46 Russel 2011: 186-91. 
face. Besides concealing perspiration and skin defects, a white face might have granted a greater contrast with eyes and lips, creating a super-feminine distinction. Facial attractiveness, enhanced by cosmetics, could manage a positive reaction by onlookers and subordinates. ${ }^{47}$ Brighter, more uniform faces - no matter how harmful lead was to the person's health ${ }^{48}$ — could have provided dominating personages with the unnatural complexions required by new virtual identities and official roles. It is not by chance that the word "cosmetic" refers to the Greek word for beauty, but also conveys ideas of totality and absolute order. Cosmetology, like writing, was a sophisticated technology for organising and managing social interaction, strategically linked to the development of early urban civilisations.

\section{Acknowledgments}

We are very grateful to Richard Allan (Department of Biology, BioArch, University of York, UK) for the GC-MS analysis. Many thanks are also due to Hassan Fazeli and to ICHTO, Islamic Republic of Iran, for the permission to collect and analyse a sample of the cosmetic substance discussed in this report. A version of this paper was initially presented at the Shahdad and the Bronze Age in South-East Iran workshop held in Cambridge in July 2011 in commemoration of Professor Ali Hakemi's work at Shahdad and forty years of excavations in south-east Iran. The authors would also like to thank the anonymous reviewers for their comments.

Massimo Vidale Istituto Superiore per la Conservazione e il Restauro Via di S. Michele 23 00153 Rome Italy massimo.vidale@beniculturali.it

$$
\begin{array}{r}
\text { Oliver Craig } \\
\text { Department of Biology } \\
\text { BioArCh } \\
\text { University of York }
\end{array}
$$

47 Russel 2011: 278-83.

48 For a vivid witness of the aesthethic effects of white lead make-ups on the high-rank concubines of the early Timurid courts see Farmanfarmaian 2000.
S Block, PO Box 373

York

YO10 $5 Y W$

$U K$

oec500@york.ac.uk

François Desset Université de Paris I Panthéon-Sorbonne 12, Place du Pantheon Paris

France

francois.desset@wanadoo.fr

Giuseppe Guida

Istituto Superiore per la Conservazione e il Restauro

Via di S. Michele 23 00153 Rome

Italy giuseppe.guida-01@beniculturali.it

Pierluigi Bianchetti

Istituto Superiore per la Conservazione e il Restauro

Via di S. Michele 23 00153 Rome

Italy

pierluigi.bianchetti@beniculturali.it

Giancarlo Sidoti

Istituto Superiore per la Conservazione e il Restauro

Via di S. Michele 23

00153 Rome

Italy

giancarlo.sidoti@beniculturali.it

Maurizio Mariottini

Istituto Superiore per la Conservazione e il Restauro

Via di S. Michele 23

00153 Rome

Italy

maurizio.mariottini@beniculturali.it

Enrico Battistella

Via Abetone 73

47203 Cesena

Italy

battistella.enrico@gmail.com 


\section{Bibliography}

Alden, J.R. 1982. "Trade and Politics in Proto-Elamite Iran", Current Anthropology 23, 6: 613-40.

Algaze, G. 1993. The Uruk World System: The Dynamics of Expansion of Early Mesopotamian Civilization, The University of Chicago Press, Chicago.

- 2008. Early Mesopotamia at the Dawn of Civilization: the Evolution of an Urban Landscape, University of Chicago Press, Chicago.

Benoit, A. 2010. "Some Thoughts on the Cosmetology of the Near East during the Third Millennium BC: Containers and Contents", in On the Track of Uncovering a Civilisation. A volume in honor of the 80th-anniversary of Victor Sarianidi, Aletheia, Sankt-Petersburg: 308-18.

Bimson, M. 1980. "Cosmetic Pigments from the Royal Cemetery of Ur", Iraq 42: 75-77.

Blanchard, W.D., Stern, E.M. and Stodulski, L.P. 1992. "Analysis of Materials Contained in Mid-4th to Early 7th Century AD Palestinian Kohl Tubes", Material Research Society Symposium Proceedings 267: 239-54.

Caldwell, J.R. 1967. Excavations at Tal-i Iblis, Illinois State Museum, Preliminary reports, No. 9, Springfield.

Cartwright-Jones, C. 2005. "Introduction to Harquus: Part 2: Kohl", in Kohl as Traditional Women's Adornment in North Africa and the Middle East, Tap Dancing Lizard Publications, accessed at the site www.harquus.com.

Chandra, M. 1973. Costumes, Textiles, Cosmetics and Coiffure in Ancient and Mediaeval India, Oriental, Delhi.

Colombo, L. 2003. I colori degli antichi, Nardini Editore, Firenze.

Costantini, L. 2003. "Le spezie nella documentazione archeologica: coriandolo, cumino e terebinto nel sito protostorico di Shahr-i Sokhta, Sistan, Iran", a panel in the exhibit Aromatica. Essenze, profumi e spezie tra Oriente e Occidente, Museo Nazionale d'Arte Orientale, Direzione Generale per i Beni Archeologici del Ministero per i Beni e le Attività Culturali, May 7th-July 8th 2003, Rome.

Dayagi-Mendels, M. 1993. Perfumes and Cosmetics in the Ancient World, The Israel Museum Jerusalem, Sabinsky Press Ltd, Tel Aviv.

Dermatas, D., Dadachov, M., Dutko, P., Menounou, N., Arienti, P. and Shen, G. 2004. "Weathering of Lead in Fort Irwin Firing Range Soils", Global Nest: the International Journal 6, 2: 167-75.

Dewick, P.M. 2009 Medicinal Natural Products. A Biosynthetic Approach, John Wiley and Sons Ltd, Chichester.

Donato, G., Branca, M.E. and Rallo A. 1975. Sostanze odorose del mondo classico, Erizzo, Venezia.

Eastaugh N., Walsh, V., Chaplin, T. and Siddall, R. 2004. The Pigment Compendium. A Dictionary of Historical Pigments, Elasevier, Amsterdam.

Farmanfarmaian, F.S. 2000. "Haft Qalam Arayish: Cosmetics in the Iranian World", Ir Sts 33, 3: 285-326.

- 2003. "Haft Qalam Arayesh in Iranian Lands: From Prehistory to the Qajar period", International Qajar Studies Association Journal 2003: 106-30.
FDA U.S. Food and Drug Administration. 2006. Kohl, Kajal, Al-Kahal, or Surma: by Any Name, a Source of Lead Poisoning, accessed at the site http://www. fda.gov/Cosmetics/ProductandIngredientSafety/ ProductInformation/ucm137250.htm

Feurer, G. 1974. "The Metabolism and Biological Actions of Coumarins", in G.P. Ellis and G.B. West (eds.), Progress in Medicinal Chemistry 10, North Holland Publishing company, Amsterdam: 85-158.

Gentelle, P. 2003. "Shahdad-Khabis, au fond du désert du Lut", Traces d'eau: Un géographe chez les archéologues, Belin, Paris: $18-53$.

Gettens, R.J., Kühn, H. and Chase, W.T. 1967. "Identification of the Materials of Paintings: Lead White", Studies in Conservation 12, 4: 125-39.

Grüner, F. 2002. "Analysis of Crystalline Materials Contained in a Palestine Kohl Vessel from the 4th century AD", Otto Graf Journal. Annual Journal on Research and Testing of Materials 13: 77-82.

Hakemi, A. 1997. Shahdad: Archaeological Excavations of a Bronze Age Center in Iran, IsIAO, Rome.

Hardy, A.D., Walton, R.I., and Vaishnav, R. 2004. "Composition of Eye Cosmetics (Kohls) Used in Cairo”, International Journal of Environmental Health Research 14, 1: 83-91.

Hatakeyama, T. and Zhenhai Liu. 1998. Handbook of Thermal Analysis, Wiley and Sons, Hoboken.

Indena. 2011. Centella asiatica Selected Triterpenes. A Highly Standardized Natural Remedy for the Maintenance of an Healthy Venous System, accessed at the site http://www. indena.com/pdf/centella.pdf

Kaboli, M.A. 1997. "Gozaresh-e dahomin fasl kavosh goruh-e bastan shenasi-e Dasht-e Lut dar mohavateh-ye bastani Shahdad (Report of the 10th season of excavation at the ancient Shahdad)", Gozaresh-ha-ye Bastan Shenasi, AR, Bd. 1, Tehran: 87-124.

Kim, E.J. and Herrera, J.E. 2010. "Characteristics of Lead Corrosion Scales Formed during Drinking Water Distribution and Their Potential Influence on the Release of Lead and Other Contaminants", Environmental Science and Technology 44, 16: 6054-61.

Law, R.W. 2011. Inter-Regional Interaction and Urbanism in the Ancient Indus Valley. A Geological Provenience Study of Harappa's Rock and Mineral Assemblage, Occasional Papers 11, Linguistics, Archaeology and the Human Past, Indus Project, Research Institute for Humanity and Nature, Kyoto.

—, Burton, J.H., Fournelle, J., Konishi, H. and Xu, H. 2010. "The Composition and Source of Lead-Based Cosmetics from Harappa", Paper presented at the 20th Conference of the European Association for South Asian Archaeology and Art (EASAA), 4-9 July 2010, Vienna.

Lee, S. and Quirke, S. 2000. "Painting Materials", in P.T. Nicholson and I. Shaw (eds.), Ancient Egyptian Materials and Technology, Cambridge University Press, Cambridge: 104-20.

Lucas, A. 1948. Ancient Egyptian Materials and Industries, Edward Arnold and Co., London. 
Mackay, E.J.H. 1938. Further Excavations at Mohenjo-Daro, Government of India, New Delhi.

Madjidzadeh, Y. 2003. Jiroft: The Earliest Oriental Civilization, Cultural Heritage Publishing Organization, Tehran.

- and Pittman, H. 2008. "Excavations at Konar Sandal in the Region of Jiroft in the Halil Basin: First Preliminary Report (2002-2008)", Iran 46: 69-103.

Mariottini, M. and Vigliano, G. n.d. Il colore nel Khmt: problemi di conservazione ed archeomineralogia, ISCR, Roma.

-, Anne, M., Dooryhee, E., Walter, P. and Tsoucaris, G. 2002. "Synthetic Hydrocerussite by Powder X-ray Diffraction", Acta Crystallographica C58: 82-84.

Meder, O.G. 1979. Klimaökologie und Siedlungsgeschichte auf dem Hochland von Iran in vor- und frühgeschichtlicher Zeit, Marburger Geographische Schriften 80, Marburg.

Mercy, M.A., Rock, P.A., Casey, W.H. and Mokarram, M.M. 1998. "Gibbs Energies of Formation for Hydrocerussite $\left[\mathrm{Pb}(\mathrm{OH})_{2} \cdot\left(\mathrm{PbCO}_{3}\right)_{2}(\mathrm{~s})\right]$ and Hydrozincite $\left\{\left[\mathrm{Zn}(\mathrm{OH})_{2}\right]_{3}\right.$. $\left.\left(\mathrm{ZnCO}_{3}\right)_{2}(\mathrm{~s})\right\}$ at $298 \mathrm{~K}$ and 1 bar from Electro-Chemical Cell Measurements", American Mineralogist 83: 739-45.

Mohamed S.M., Bosila, H.A., Sharabasy, S.F.E., Ibrahim, I.A. and Refay K.A. 2001. Phytochemical Screening of Some in vivo and in vitro Date Palm Tissue, Al-Ain, United Arab Emirates.

Moorey, P.R.S. 1999. Ancient Mesopotamian Materials and Industries, the Archaeological Evidence, Eisenbrauns, Winona Lake.

Morton, J.F. 1987. Fruits of Warm Climates, Florida Flair Books, Miami.

Nriagu, J.O. 1983. Lead and Lead Posioning in Antiquity, Wiley, New York.

Parry, C. and Eaton, J. 1991. "Kohl: a Lead-Hazardous Eye Makeup from the Third World to the First World", Environmental Health Perspectives 94: 121-23.

Pollock, S. 2006. Ancient Mesopotamia. The Eden that Never Was, Cambridge University Press, Cambridge.

Pottier, M.-H. 1984. Matériel funéraire de la Bactriane méridionale de l'âge du bronze, Mémoire $\mathrm{n}^{\circ}$ 36. 5, Éditions Recherche sur les Civilisations, Paris.

Potts, D.T. 1999. The Archaeology of Elam, Cambridge University Press, Cambridge.

Rahbar, M.H., White, F., Agboatwalla, M., Hozhbari, S. and Luby S. 2002. "Factors Associated with Elevated Blood Lead Concentrations in Children in Karachi, Pakistan", Bulletin of the World Health Organization 80, 10: 769-75.

Rossi-Osmida, G. 2007. "Le Carovane della Bellezza", in G. Ligabue and G. Rossi-Osmida, Sulla Via delle Oasi. Tesori dell'Oriente Antico, Il Punto, Trebaseleghe: 262-70.

Russel, R. 2011. "Why Cosmetics Work", in R.B. Adams Jr., N.
Ambady, K. Nakayama and S. Shimojo (eds.), The Science of Social Vision, Oxford University Press, New York: 186283.

Salvatori, S. and Vidale, M. 1982. "A Brief Surface Survey of the Proto-Historical Site of Shahdad (Kerman, Iran)", Rivista di Archeologia 6: 5-10.

Sana Ullah, M. 1931. "Notes and Analyses", in Sir J. Marshall, Mohenjo-Daro and the Indus Civilization, A. Probsthain, London: 691.

Sotiropoulou S., Perdikatsis, V., Apostolaki, Ch., Karydas, A.G., Devetzi, A. and Birtacha K. 2010. "Lead Pigments and Related Tools at Akrotiri, Thera, Greece. Provenance and Application Techniques", Journal of Archaeological Science 37, 8: 1830-40.

Subbarayappa, B.V. (ed.) 1999 Chemistry and Chemical Techniques in India, Pauls Press, New Delhi.

Ungar, T., Martinetto, P., Ribarik, G., Dooryhee, E., Walter, Ph. and Anne, M. 2002. "Revealing the Powdering Methods of Black Makeup in Ancient Egypt by Fitting Microstructure Based Fourier Coefficients to the Whole X-ray Diffraction Profiles of Galena", Journal of Applied Physics 91, 4: 2455-65.

Vats, M.S. 1940. Excavations at Harappa, Government of India Press, Delhi.

Vidale, M. and Desset, F. in press. "Mahtoutabad (Konar Sandal South, Jiroft). Preliminary Evidence of Occupation of a Halil Rud Site in the early 4th Millennium BCE", in C.A. Petrie (ed.), Ancient Iran and its Neighbours. Local Developments and Long-Range Interactions in the 4th Millennium BC, Oxbow, Oxford.

Walter, P. 1999. "La chimie dans les fards de l'Égypte ancienne", L'Actualité Chimique, Chimie et vie quotidienne, Numéro spécial, novembre 1999: 134-36.

-, Martinetto, P., Tsoucaris, G., Breniaux, R., Lefebvre, M.A., Richard, G., Talabot, J. and Dooryhee, E. 1999. "Making Make-up in Ancient Egypt", Nature 397: 483-84.

Welcomme, E., Walter, P., van Elslande, E. and Tsoucaris, G. 2006. "Investigation of White Pigments used as Make-up during the Greco-Roman Period", Applied Physics A: Materials Science and Processing, Special issue: Materials Science and Cultural Heritage 83, 4: 551-56.

Woolley, C.L. 1934. Ur Excavations. Volume II. The Royal Cemetery. A Report on the Predynastic and Sargonid Graves Excavated between 1926 and 1931, text and plates, Publications of the Joint Expedition of the British Museum and of the Museum of the University of Pennsylvania to Mesopotamia, Oxford.

Yaghmaie, E. 1999. "How Women Applied Makeup 3000 Years Ago", Zanan; Social Magazine 52: 49-52. 